\title{
Art in evidence-based nursing practice from the perspective of Florence Nightingale
}

\author{
A arte na prática baseada em evidências na enfermagem sob a perspectiva de Florence Nightingale \\ El arte en la práctica basada en evidencias en la enfermería bajo la perspectiva de Florence Nightingale
}

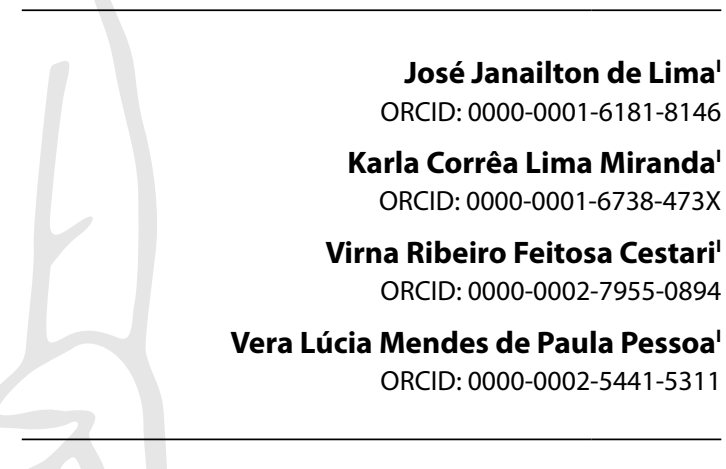

'Universidade Estadual do Ceará. Fortaleza, Ceará, Brazil.

How to cite this article:

Lima JJ, Miranda KCL, Cestari VRF, Pessoa VLMP. Art in evidence-based nursing practice from the perspective of Florence Nightingale.

Rev Bras Enferm. 2022;75(4):e20210664. https://doi.org/10.1590/0034-7167-2021-0664

Corresponding author:

José Janailton de Lima

E-mail: jjanailtim@gmail.com

EDITOR IN CHIEF: Álvaro Sousa ASSOCIATE EDITOR: Rafael Silva

Submission: $09-14-2021$

Approval: 11-03-202

\section{ABSTRACT}

Objectives: to discuss, in the light of Florence Nightingale, the historical position of art as a constituent device of evidence-based nursing practice. Methods: reflective study anchored in the writings of Nightingale and other researchers with whom it is possible to have a profound dialogue on the theme "art in nursing". Results: art is related to two essential elements in the practice of nursing: knowledge and skill. Understanding science as knowledge and art as skill leads to the idea that both make it possible to combine technical competence, compassion, ethics, and individualization of care. Final Considerations: the art of nursing is the continuous exercise of detailed perception, so that the subjective aspect becomes the center to which the nurse's gaze converges, that which will allow them to unveil the "truth" posed by the patient, resulting in the best intervention for him.

Descriptors: Art; Nursing Practice Patterns; Evidence-Based Nursing; Science in the Arts; Nursing

\section{RESUMO}

Objetivos: discutir, à luz de Florence Nightingale, sobre a posição histórica da arte enquanto dispositivo constituinte da prática baseada em evidências na enfermagem. Métodos: estudo reflexivo ancorado nos escritos de Nightingale e de outros pesquisadores com os quais se pode dialogar profundamente sobre a temática "arte na enfermagem". Resultados: a arte possui relação com dois elementos essenciais no exercício da enfermagem: conhecimento e habilidade. Compreender ciência como conhecimento e arte como habilidade leva à ideia de que ambas permitem aliar competência técnica, compaixão, ética e individualização dos cuidados. Considerações Finais: a arte da enfermagem é o exercício contínuo da percepção detalhada, de modo que o aspecto subjetivo se torna o centro para o qual converge o olhar do enfermeiro, aquele que o permitirá desvelar a "verdade" posta pelo paciente, resultando na melhor intervenção para ele.

Descritores: Arte; Padrões de Prática em Enfermagem; Enfermagem Baseada em Evidências; Ciência nas Artes; Enfermagem.

\section{RESUMEN}

Objetivos: discutir, basado en Florence Nightingale, sobre la posición histórica del arte mientras dispositivo constituyente de la práctica basada en evidencias en la enfermería. Métodos: estudio reflejo ancorado en los escritos de Nightingale y otros investigadores con los cuales se puede dialogar profundamente sobre la temática "arte en la enfermería". Resultados: el arte posee relación con dos elementos esenciales en el ejercicio de la enfermería: conocimiento y habilidad. Comprender ciencia como conocimiento y arte como habilidad lleva a la idea de que ambas permiten aliar competencia técnica, compasión, ética e individualización de los cuidados. Consideraciones Finales: el arte de la enfermería es el ejercicio continuo de la percepción detallada, de modo que el aspecto subjetivo se vuelve el centro para lo cual converge el mirar del enfermero, eso que lo permitirá desvelar la "verdad" puesta por el paciente, resultándole en la mejor intervención.

Descriptores: Arte; Pautas de la Práctica en Enfermería; Enfermería Basada en la Evidencia; Ciencia en las Artes; Enfermería. 


\section{INTRODUCTION}

The current health panorama has substantially reinforced the use of scientific evidence in therapeutic approaches as a way of offering the best decision. Nursing, as a profession essentially focused on meeting the needs of human beings in different health situations, uses the concept of practice based on evidence or best practices to support its clinical practice and provide quality care.

By evidence-based practice (EBP) it is understood a set of techniques, processes, and activities understood as the best to perform a given task, consistent with the values, objectives, evidence of health promotion, and understanding of the environment in which the practice takes place ${ }^{(1)}$. In nursing, in addition to technique - so closely related to professional practice - , requires extensive knowledge of values and beliefs, as well as seeking out skills that involve intuition for the most appropriate decision-making.

In the institutional health context, the use of EBP has been supported by scientific studies that value the empirical-mathematical logic through positivism - the dominant philosophical current in the health sciences. From it derives the application of quantitative studies with the purpose of discovering factual invariance, and then formulating rules common to all individuals ${ }^{(2)}$.

However, establishing rules applicable to all individuals seems to be at odds with the care practice model characteristic of the nursing team, in which care assumes a fundamental aspect in daily activities. Since its emergence as a profession, nursing has faced changes in its practice, influenced by historical, social, political(3), and subjective factors that culminate in a challenge for nursing: the inclusion of the patient in the production of this care.

The exercise of caring for a human being is not a simple activity given that each person is unique in their essence, and this depends on the particularities experienced in situations that make them vulnerable, such as during physical and/or mental imbalance ${ }^{(3)}$. Thus, the application of EBP as currently instituted, for the most part, may not include the subjectivity involved in the nursing care process to the same extent.

In the field of subjectivity, art establishes a fertile real-time dialogue with the world through physical and metaphysical realities; and it is, so to speak, closer to the complexity of life and processes involving human beings. According to Nébia Almeida, "nursing is also a subjective art because it imagines, interprets, intuits, gets emotional, it is a sensitive science (...)", promoting interaction just as a work of art provokes a response on those who observe it ${ }^{(4)}$.

The understanding that care practices are increasingly anchored in research based on scientific evidence from the results of positivist studies is already clear for nursing, but there is a growing movement for the development of studies with a qualitative emphasis, as well as for quality of the care offered to the patient.

Nursing performs care that expresses a "know-how" based on science, art, ethics, and aesthetics, directed to the needs of the individual, the family, and the community ${ }^{(5)}$, that is, it greatly requires the use of the method of qualitative research, anchored in subjectivity.

Florence Nightingale was the first nurse and researcher to mention the art in a writing about nursing and did so at a time when this profession had recently come out of ostracism, as a result of her efforts during the Crimean War. The Lady of the Lamp did not go into detail, but left clues so that interpretations could emanate from her letters and books. In one of them, Miss Nightingale compared nursing with the work of an artist, concluding that there would be similarities, but with a certain superiority of the first profession over the second.

It is understood that EBP is essential for health, but it is necessary for nursing to add other elements in the performance of this practice so that it is related to their know-how. However, logical reasoning, despite its relevance, does not alone answer all the questions in the field of nursing, but, when connected to creativity, development of techniques, and the capacity for reflection and abstraction, it has a greater capacity to understand the complexity of the human being in contemporaneity.

Despite the recognition of the relevance of art to nursing since the 19th century, nursing still lacks knowledge of it. This gap may be due to the strong appeal initiated in Brazil by foreign researchers in the development of nursing theories to consolidate the profession in the role of science in the 1950s. Therefore, it is necessary to seek to bring closer and strengthen the association between EBP and art in nursing.

Therefore, the following questions are asked: What statements were made by Florence so that art could be compared to nursing? How can art be strengthened as a device for evidence-based nursing practice?

\section{OBJECTIVES}

To discuss, in the light of Florence Nightingale, the historical position of art as a constituent device of evidence-based nursing practice.

\section{THE RESEARCH ROUTE}

This is a reflective study anchored in the writings of Florence Nightingale and other researchers with whom it is possible to have a profound dialogue on the theme "art in nursing". Based on the period in which the aforementioned researcher lived (1820 - 1910), it was decided to use her long-published classics, but which bring the presuppositions of art in the nursing profession, the main reason for the elaboration of this work. A detailed search for excerpts was carried out in her letters and/or books whose content established a relationship with the element "art in nursing". In view of the use of words that have long been out of use in the English language, the assistance of a translator specialized in English literature was sought.

After reading the material, a record was drawn up containing all the fragments that mentioned the word "art" for later submission to the translator. With the translation in hand, another reading was carried out to contextualize the use of the term "art" in the documents.

\section{From the art of artists to the art of nursing}

To reflect on the insertion of art in nursing, it is essential to go back to the Middle Ages, when all the knowledge of the time 
was gathered in arts. The framework of university teaching in the Middle Ages was formed by grouping disciplines around the trivium (logic, grammar, and rhetoric) and the quadrivium (geometry, arithmetic, music, and astronomy). When they came together, they formed the seven arts or simply liberal arts, understood as essential for the formation of a full man, free from a profession - considered proper to serfs. There was no distinction between art and science as we know it today. A set of knowledge was offered based on the Aristotelian concept that art would be the ability to create based on the search for truth. Differing from the liberal arts, there were the mechanical arts, which encompassed disciplines focused on the production of utilities, such as tools and objects in common use.

With the advent of positivism, scientific and artistic knowledge were divided. While science was consolidated producing knowledge based on the principle of reason, logic, and mathematical thinking, the concerns of art would incorporate subjectivity, morality, and culture as discussions of an individual nature and the judgment of taste ${ }^{(6)}$. As scientific knowledge moved away from art and philosophy, efforts were focused on the expansion of technology through the emerging industrialism of the Old Continent.

The Industrial Revolution had its cradle in the United Kingdom and provoked intense transformations in the economy, in the means of production, and in life in society. It was within this panorama that Florence Nightingale lived, member of a rich and aristocratic family of farmers and miners. By opting for nursing - an unqualified and unthinkable activity for a woman of her social condition - Florence refused to marry, preferring to dedicate herself to the sick.

Her opinion on the most varied subjects and, above all, her keen perception when the subject was the care of the sick made her stand out among the English. She paid attention to the body, environment, safety, ventilation, patient profiles, epidemiological data, among others, which can be observed especially in her most widespread works - Notes on Nursing and Notes on Hospitals.

Having revolutionized the way care practices were viewed and performed, Florence spent much of her life preoccupied with training nurses at her school at Saint Thomas Hospital, using the prestige she had to denounce the conditions of English hospitals and writing her impressions on nursing. In 1871, a short post-mortem biography was published dedicated to Agnes Elizabeth Jones (one of her lady nurses), in which she writes the most emblematic definition of nursing.

Nursing is an art; and if it is to be made an art, it requires as exclusive a devotion, as hard a preparation, as any painter's or sculptor's work; for what is the having to do with dead canvas or cold marble, compared with having to do with the living body - the temple of God's spirit? It is one of the Fine Arts; I had almost said the finest of the Fine Arts $^{(7)}$.

When bringing nursing and art together, The Lady with the Lamp did not do it clearly, but left some clues scattered in publications - mostly letters - with which arguments can be made in search of this understanding. Also in the same work, Miss Nightingale added:
I have seen somewhere in print, that nursing is a profession to be followed by the "lower middle-class." Shall we say that painting or sculpture is a profession to be followed by the "lower middle-class"? Why limit the class at all? Or shall we say that God is only to be served in his sick by the "lower middle-class"? The poorest child without shoes, the most highly-born, have alike followed all these professions with success, have alike had to undergo the hardest work, if for success. There is no such thing as amateur art; there is no such thing as amateur nursing ${ }^{(7)}$.

At the beginning of school at Saint Thomas, Florence was concerned with finding ways to make nursing a socially respected profession, so much so that, when selecting her students, she opted for girls from rich families to occupy the highest positions in the institutions.

In the aforementioned excerpt, she presents nursing as an extremely qualified activity equivalent to painting and sculpture (arts revered by high social strata) and, in doing so, questioned the practice of nursing by lower-level women. Caring for the sick was a noble task surrounded by Christian values, in which the sick was the purest reflection of divinity and deserving of a refined treatment to be offered by those who could receive the best care, that is, the aristocracy.

Florence also compared nursing and art to seek recognition while she called for salary improvements by telling us:

It appears to be the most futile of all distinctions to classify as between "paid" and unpaid art, so between "paid" and unpaid nursing - to make into a test a circumstance as adventitious as whether the hair is black or brown, namely, whether people have private means or not, whether they are obliged or not to work at their art or their nursing for a livelihood. Probably no person ever did that well which he did only for money. Certainly no person ever did that well which he did not work at as hard as if he did it solely for money. If by amateurs in art or in nursing are meant those who take it up for play, it is not art at all, it is not nursing at all. You never yet made an artist by paying him well. But-an artist ought to be well paid(7).

According to Nightingale, true nursing could only be exercised by well-prepared, serious, and committed women, otherwise it would be anything but nursing. Even if it was a profession that required self-denial to exercise it, it would require a lot of effort to reach a level of excellence, and all that dedication should be paid, like any artist. Now, if artists are paid for their art and nursing is an art, their "artists" should be very well paid, as they deal with the most "beautiful art": the human body (receptacle of the soul).

During the evolution of art, the Frenchman Charles Batteux published, in 1746, Les Beaux-arts réduits à un même principe, a book in which he unites beauty and taste to imitate nature and, with this, achieve an ideal model of perfection. Charles was the first to use the term "fine arts" for the set of disciplines that sought the expression of beauty in its own right, bringing together music, sculpture, painting, dance, poetry, eloquence, and architecture.

In Victorian England, art played an important role, particularly in the upper classes. It should be pleasing to the eye, bring lightness, be simple to be useful, elevate the spirit of those who possess it, becoming an object of consumption, a material good, since art is an activity highly valued by members of the aristocracy 
through the acquisition of paintings and statues, promotion of exhibitions, literary soirees, and operas.

As opposed to the fine arts, there were the applied arts. With a functional character, these were intended for the lower classes or involved in the production of large-scale objects during the Industrial Revolution. The dichotomy between fine arts and applied arts was intensified by artists and artisans delimiting the activities of each group so as not to be confused.

During this period, there was a separation between artisancraftsmen, responsible for manual work characterized by repetition, using knowledge acquired by common sense, and those now called artists, who used a plurality of scientific knowledge arising from mathematics, geometry, arithmetic, chemistry, and physics in order to create works worthy of admiration ${ }^{(8)}$. It was necessary for art to reach the status quo of science prevailing in the Age of Enlightenment - everything was valid to elevate art and distance it from popular taste and opinion. Likewise, nursing should also be protected by professionals who combine science, respect, practice, training, and patience.

Miss Nightingale's contact with various fields of knowledge may have given her conditions to deepen her studies in experimental and positivist sciences, and with that, use this knowledge arising in the education of her students. During internships in Kaiserswerth and Paris, she realized that a good nurse would need excellent preparation, adding theoretical and practical classes; thus, she became the first nurse to give a more scientific character to the profession.

\section{From the art of nursing to the art of evidence}

Through Florence's writings, art is related to two essential elements in the practice of nursing: knowledge and skill. On the one hand, there is scientific knowledge arising from observation and formal preparation using mathematics, physics, chemistry, anatomy, and biology; on the other hand, the acquisition of skills to care for the sick would be a condition for nursing to be raised to an art level. Otherwise, it would just be amateur nursing, as she herself says.

Other scholars see art as an inherent knowledge of nursing by integrating technique, intuition, and sensitivity ${ }^{(9)}$. Art as a skill or technique was disseminated in the profession through the maxim "nursing is the art of caring", but, over time, the meaning of art has undergone some changes.

Until the end of the 18th century, the term "art" was used in several subjects to designate expertise or mastery in the field of mathematics, medicine, or fishing. Philosophy defines "art" as intuition, expression, projection ${ }^{(6)}$. The etymology points out that the term follows the Latin word ars, whose meaning is ability.

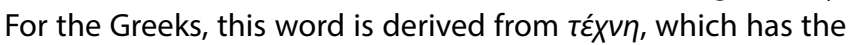
same morphological structure as TEXvıkóv (in Latin, techné or technique). The same root would end up causing the misunderstanding that "art" and "technique" would be synonymous. The

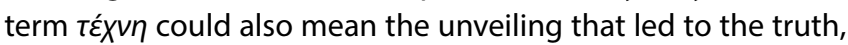
that is, the unveiling that causes an opening, achieved only with

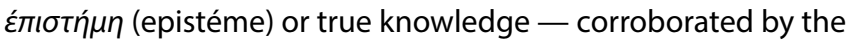
concept proposed by Aristotle. It is interesting to note that this knowledge of the truth is understood by us as science, and it is possible to conclude that science and art seek the unveiling that leads to the truth using knowledge acquired jointly.

The opposition between science and art was shaped based on a thought that separated this knowledge, giving them differentiated and even opposing characteristics, languages, methods, and epistemological links as a result of the positivist thought proposed by René Descartes ${ }^{(6)}$. From that period onwards, the search for the status of science became the object of greed in all fields of knowledge, but for nursing - until then a mere activity, like that of artisans, disqualified, servile - this effort would not be easy. However, Florence presents us with a broader view when stating:

The patient is for us a triple interest: the intellectual interest as a case, which requires closer observation of the facts, to be explained by the lecture and clinical teaching; the moral interest, as a creature to whom we must attend to, while it is in our care [...]; the technical interest, through which we learn what to do for the patient and how to do $\mathrm{it}^{(10)}$.

Nursing [...] is a very serious and pleasant thing, like life, requiring training, experience, devotion, not being erratic, it requires patience, a power to accumulate, instead of losing all these thing ${ }^{(10)}$.

By perceiving the patient as a being who demands knowledge acquired through observation and teaching, zeal and responsibility, as intrinsic prerogatives, in addition to extreme aptitude, Miss Nightingale was grouping EBP principles. A key element for the emergence of these practices is the existence of competences, seen as a set of knowledge and skills to achieve certain results.

Thus, EBPs are essentially formed by a triad that encompasses the best results of scientific research, clinical expertise, and the needs of each patient/individual. Understanding science as knowledge and art as skill (a term used by Florence) leads to the idea that both make it possible to combine technical competence, empathy, ethics, and individualized care - common words in nurses' discourse, but relegated to spaces where evidence tends to dominate.

By accumulating a body of knowledge derived from the physical, biological, and behavioral sciences, nurses did so to develop theories of care - the focus of nursing science.

\section{Study limitations}

The search for recent publications presented itself as a frequent challenge during the elaboration of the manuscript.

\section{Contributions to the field of nursing}

The concern of nursing researchers to ensure a place for nursing in the field of science ended up distancing us from what might make it more human: its proximity to art. It is time to undertake studies no longer so that one can replace the other, but so that, together, they can better respond to society's concerns. The premise that nursing is both a science and an art leads us to seek a point of convergence and balance for this knowledge within the profession. The dissemination of nursing rooted on science and art, not only through the use of the cliché "art of care", is a 
sine qua non condition in which its professionals will be able to know themselves to act confidently in their role.

\section{FINAL CONSIDERATIONS}

Going deeper into Florence's writings, it can be said that the use of art in nursing cannot be treated as a divine aptitude, present only in the chosen ones, as has been propagated among professionals in the field. The art of nursing is the continuous exercise of the detailed perception of Being cared for, so that the subjective aspect becomes the center to which the nurse's gaze converges, the one that will allow them to unveil the "truth" posed by the patient, resulting in the best intervention for him. In this sense, the art of nursing is strengthened in EBP when the patient (work of art) is observed in detail in order to reveal it, leading to an interpretation for action, as an artist does when creating.

Evidence-based practice derives from the development of decision-making skills, but for that, the nurse must acquire the status of the Renaissance artist, as one who perceives science and art as something indivisible and uses it in everyday life to intervene, thus distancing itself from an artisanal, repetitive, mechanized practice.

\section{FUNDING}

Fundação Cearense de Apoio ao Desenvolvimento Científico e Tecnológico - FUNCAP.

\section{REFERENCES}

1. Erdmann AL, Andrade SR, Mello ALSF, Drago LC. Secondary Health Care: best practices in the health services network. Rev Latino-Am Enfermagem [Internet]. 2013 [cited 2019 Oct 26];21(9):131-139. Available from: http://www.scielo.br/pdf/rlae/v21nspe/17.pdf

2. Minayo MCS. O desafio do conhecimento: pesquisa qualitativa em saúde. 13. ed. São Paulo: Hucitec; 2013. 406 p.

3. Alves SGS, Vasconcelos TC, Miranda FAN, Costa TS, Sobreira MVS. Aproximação à subjetividade de enfermeiros com a vida: afetividade e satisfação em foco. Esc. Anna Nery [Internet]. 2011 [cited 2019 Dec 21];15(3):511-7. Available from: https://www.scielo.br/pdf/ean/v15n3/ a10v15n3.pdf

4. Vale EG, Pagliuca LMF. Construção de um conceito de cuidado de enfermagem: contribuição para o ensino de graduação. Rev Bras Enferm [Internet]. 2011 [cited 2019 Dec 21];64(1):106-13. Available from: https://www.scielo.br/pdf/reben/v64n1/v64n1a16.pdf

5. Santos I, Figueiredo NMA, Duarte MJR, Sobral VRS, Marinho AM. Enfermagem Fundamental: realidades, questões, soluções. São Paulo: Atheneu; 2002. 302 p.

6. Ferreira FR. Ciência e arte: investigações sobre identidades, diferenças e diálogos. Educ Pesqui São Paulo. 2010[cited 2020 Mar 11];36(1):26180. Available from: http://www.scielo.br/pdf/ep/v36n1/a05v36n1.pdf

7. Nightingale F. Una and the lion. Cambridge: Riverside Press; 1871. 22 p.

8. Jimenez M. O que é estética?. São Leopoldo: Ed. Unisinos; 1999. 208 p.

9. Torralba-Roselló F. Antropologia do cuidar. Petrópolis: Vozes; 2009. 200 p.

10. Nightingale F. To the Nurses and Probationers trained under the nightingale fund. London: Spottiswoode \& Co.;1897. 17 p. 